Article

\title{
Perceptions of Professional Competences in Physical Education Teacher Education (PETE)
}

\author{
Sonia Asún * (1), Miguel Tomás Chivite and $\mathrm{M}^{\mathrm{a}}$ Rosario Romero \\ Faculty of Health and Sport Sciences, University of Zaragoza, 22001 Huesca, Spain; mchivite@unizar.es (M.T.C.); \\ rromero@unizar.es (M.R.R.) \\ * Correspondence: sonasun@unizar.es; Tel.: +34-974-238423
}

Received: 12 April 2020; Accepted: 5 May 2020; Published: 7 May 2020

\begin{abstract}
Students' skills acquisition is one of the main aims of higher education institutions. On the one hand, the development of professional competences is important, but on the other hand, it is known that professionals who feel competent have a more intrinsic motivation in their jobs. The goal of this study was to describe and detail the perceptions of students, graduates, and their university tutors about the level of acquisition by students of professional competences. The methodology was based on a descriptive and comparative study that included a total sample of 2075 participants of the Degree in Primary Teaching and the Degree in Physical Activity and Sport Science. All of them came from 21 different universities of Spain: 345 university tutors, 1243 students, and 487 graduates. The instrument used was a competences perception questionnaire. The statistical analysis included means, standard deviations, and an ANOVA analysis. The results show discrepancies in the perceptions of proficiency levels between students and graduates, on one hand, and university tutors, on the other. Likewise, there was general agreement that competences related to critic capacity and motor games were the most acquired and programs for individuals with special needs were the least acquired.
\end{abstract}

Keywords: perceptions; competences; higher education; physical education teacher education

\section{Introduction}

The perception of professional competences and real competences acquired during the physical education teacher education (PETE) can have an essential influence on the future quality of education. Education and skills acquired by university students are known to influence the workplace. Skills acquired by students during training can affect both the volume of work and the worker's satisfaction. Besides, there is a mismatch between the skills available after initial training and the skills required at work [1].

In Spain, there are still few studies about perceived competence from students' and graduates' point of view. Recently, quite a few scholars have been conducting research on the subject (e.g., [2-6]). Therefore, it is important to carry out studies to test competences in higher education [7] and to get students' and graduates' beliefs, as well as that of their university tutors.

The models of educating teachers have undergone various changes in recent times, evolving from the well-known and entrenched traditionalist approaches to more competence-based approaches. The competency-based training model is the new frame of reference, which guides higher education institutions in the design of their training programs [8]. University education is gradually transitioning through a focus on implementing, analyzing, and studying the effectiveness of new training models based on established competencies [9].

The focus has moved from the more technical and reductionist competence approaches of the seventies, to competence approaches that are more holistic and of greater complexity due to the 
integration of techniques, strategies, interpersonal, and emotional competences, the latter being those that are currently receiving greater focus within universities [10].

Regarding the definition of the term 'competence', it is generally understood as a combination of knowledge, skills, and individual characteristics, such as motivation, self-awareness, personality traits, attitudes, beliefs, values, and interests, which can be measured and can be determinants of differences in performance [11]. Competence training is related to the type of effective actions that are oriented towards the resolution of problems and the improvement of social contexts, applying knowledge and being effective in the use of resources [12]; always from a perspective of self-responsibility. In short, it delivers the ability to solve contextualized problems with self-responsibility, using knowledge, skills, and individual characteristics that can be measured and that are decisive in the optimal resolution of the complex situations encountered.

In the opinion of some authors, specific competences, also referred to as professional competences, are related to technical issues (knowledge) and methodological aspects (know-how), while generic competences, also known as transversal competences, remain closer to participatory behavior (knowing how to act) and personal behavior (knowing how to be) [10].

In particular, the specific competences in the Spanish universities offer the PETE teachers the opportunity to correspond to a greater or lesser extent with so-called teaching competences. Panel members design these competencies derived from various curricular guidelines and textbook sources of the government. Some authors $[13,14]$ have focused their reflections in recent times on this area of study.

In the wider context, it can be said that teaching competence has long been an object of study that has been analyzed and researched in depth. Nevertheless, it should be clarified that in some of these studies it is advisable to determine when reference is made to teaching competence as opposed to professional effectiveness [15]. In general, many studies have focused on competence from the perspective of current or future teaching professionals (e.g., [16,17]). However, as indicated in a recent study [18], it is still important to clarify what is meant by a competent or an effective teacher; and more specifically, within European countries, since most of the research on this subject is currently centered in the United States [19].

According to students' acquisition of competences during their PETE, several research studies have focused on highlighting that in competency training models it is important, first of all, to corroborate the existence of an adequate alignment between the competency training model and the way it is assessed [20]. This is an essential issue for the effective acquisition of competencies by future professionals and it is known that several studies have tried to explain this topic (e.g., [21-23]).

On the one hand, likewise, some research studies have considered it vitally important to obtain data on perceived competence from students, as future professionals, so some studies have been oriented towards the need to identify the student's perspective in relation to the acquisition of competences through self-evaluation [24].

On the other hand, there has been considerable effort in some research to consider the opinions and perceptions of university tutors regarding competency-based training models [25]. Although, there has not been a research effort to obtain their opinions about the level of students' competences.

However, at the same time, the interest in knowing the perceptions of more agents and not only the students' perceptions is growing. One of the last studies published, [26], showed this point of view. The authors analyzed students, teachers, and employers' perceptions. The results showed a disparity of different agents' perceptions. In their opinion, this map of perceptions is the right way to improve the curriculums in higher education.

Within PETE programs there has also been an interest in studying the most effective alignment between assessment systems and the competencies that are intended to be acquired $[27,28]$ and, furthermore, in analyzing the perception of the students themselves and their tutors' perceptions of the students' acquisition of competences during their initial training period $[29,30]$. 
It can be seen, therefore, that in the field of research regarding the study of competences acquired through the PETE, it is considered fundamental to collect data from the students themselves, from graduates who are experiencing their first engagement with the workplace, their university tutors, and, of course, from an analysis of the alignment and consistency of the contemporary training models themselves.

A variety of designs have been employed in these previous studies, although they have been predominantly quantitative in nature. This approach was also chosen for this current study, as explained beneath.

The study developed the below aims for investigating PETE in Spain, both in the Bachelors' Degree in Primary Education (DPE) and in the Bachelors' Degree in Physical Activity and Sports Sciences (DPASS) - more specifically, the perception of the acquisition of specific competences from the perspective of current students, graduates, and university tutors. The ultimate purpose was to identify these groups' viewpoints and to have a map of the level of acquisition of physical education teaching competences within the PETE.

\section{Materials and Methods}

\subsection{Participants}

A non probabilistic, snowball sampling was taken. In this form of sampling, researchers find participants and ask them to recruit other sample subjects [31]. The final recruitment was composed of 2075 subjects ( 890 women and 1185 men). Of these total, 345 were university tutors of the DPE or of the DPASS in Spain that had taught on either of those programs in any of the four preceding academic years; 1243 were students on the final year of their course; and 487 were graduates from the last five cohorts of the previously mentioned degree courses in Spain. All of them came from 21 different universities that covered a wide spectrum of Spanish geography, fulfilling the criterion of heterogeneity of the population (Table 1).

Table 1. Participants.

\begin{tabular}{cccccc}
\hline & \multicolumn{2}{c}{$\%$ Gender } & \multicolumn{2}{c}{$\%$ Degree } \\
\cline { 2 - 6 } & $\mathbf{N}$ & Male & Female & PEF & PASS \\
\hline Students & 1243 & $56.5 \%$ & $43.5 \%$ & $68.0 \%$ & $32.0 \%$ \\
Tutors & 345 & $56.8 \%$ & $43.2 \%$ & $60.4 \%$ & $39.6 \%$ \\
Graduates & 487 & $58.9 \%$ & $41.1 \%$ & $39.0 \%$ & $61.0 \%$ \\
\hline
\end{tabular}

\subsection{Instruments}

Three scales were designed for the analysis of the perceptions that tutors, students, and graduates had about the level of acquisition by students of generic or personal competences, generic teaching, and specific physical education teaching competences during their initial training in undergraduate courses. Each of the three groups were asked, in relation to all of the subjects on their degree course, to say to what extent they believed that the students had developed each of twenty-two teaching competences (Table 2). Responses were assessed using a Likert-type response scale with five points of agreement: 0 (nothing); 1 (little); 2 (moderately); 3 (a lot); and 4 (very much). The items used were the competences incorporated in the corresponding "Libros Blancos" of the DPE and in DPASS [32,33] were textbooks sources, edited by the Spanish government, which include some curricular guidelines for Spanish universities. 
Table 2. Physical education specific teaching competences.

\begin{tabular}{|c|c|c|c|c|c|}
\hline \multicolumn{2}{|r|}{ Competences } & \multicolumn{2}{|c|}{ Spec. } & \multicolumn{2}{|c|}{ Gen. } \\
\hline & & A & B & $\mathrm{C}$ & $\mathbf{D}$ \\
\hline 1 & Design, apply, and analyze didactic interventions in the discipline of PE & & * & & \\
\hline 2 & $\begin{array}{l}\text { Develop and implement PE programs that facilitate the effective participation of } \\
\text { students with special educational needs }\end{array}$ & & * & & \\
\hline 3 & $\begin{array}{l}\text { Design, develop, and evaluate teaching-learning processes related to physical } \\
\text { activity and sport with attention to the individual and the contextual } \\
\text { characteristics of participants }\end{array}$ & & * & & \\
\hline 4 & $\begin{array}{l}\text { Understand and promote the different motor manifestations that are part of your } \\
\text { traditional culture }\end{array}$ & * & * & & \\
\hline 5 & Understand psychomotor development and its evolutionary maturation & * & & & \\
\hline 6 & $\begin{array}{l}\text { Understand physical capacities and the factors that determine their evolution and } \\
\text { know how to apply their specific technical foundations }\end{array}$ & * & * & & \\
\hline 7 & $\begin{array}{l}\text { Understand the biological and physiological fundamentals of the human body in } \\
\text { relation to physical activity }\end{array}$ & * & & & \\
\hline 8 & $\begin{array}{l}\text { Understand the elements and foundations of bodily expression and nonverbal } \\
\text { communication and their formative and cultural value }\end{array}$ & * & & & \\
\hline 9 & $\begin{array}{l}\text { Understand the basics of introducing school sports and design specific tasks to be } \\
\text { used in the field of education }\end{array}$ & * & * & & \\
\hline 10 & $\begin{array}{l}\text { Have strategies for applying the elements of health regarding hygiene and } \\
\text { nutrition in educational practice }\end{array}$ & & * & & \\
\hline 11 & $\begin{array}{l}\text { Deliver teaching strategies that promote the acquisition of regular physical } \\
\text { activity habits }\end{array}$ & & * & & \\
\hline 12 & Know how to use games as a teaching resource and as teaching content & & * & & \\
\hline 13 & $\begin{array}{l}\text { Know how to apply the fundamentals (techniques) of physical activities within the } \\
\text { natural environment }\end{array}$ & & * & & \\
\hline 14 & Know how to use assessment instruments in the discipline of PE & & * & & \\
\hline 15 & $\begin{array}{l}\text { Promote complementary activities related to physical activity and sports inside } \\
\text { and outside the educational arena }\end{array}$ & & * & * & \\
\hline 16 & Respond to issues of diversity in PE practices & & * & * & \\
\hline 17 & $\begin{array}{l}\text { Be able to reflect on teaching and learning process, different organizational types, } \\
\text { and different methodologies within PE classes }\end{array}$ & * & & & * \\
\hline 18 & Understand the corporal and motor skill educational processes & * & & & \\
\hline 19 & $\begin{array}{l}\text { Design, modify, and/or adapt to the educational context of motor situations } \\
\text { oriented to the development and improvement of motor skills }\end{array}$ & & * & & \\
\hline 20 & $\begin{array}{l}\text { Design, develop, and evaluate teaching-learning processes related to motor skills, } \\
\text { with attention to the individual and the contextual characteristics of participants }\end{array}$ & & * & & \\
\hline 21 & $\begin{array}{l}\text { Analyze and communicate, in a critical and substantiated way, the value of } \\
\text { physical activity and sport and their contribution to the development and } \\
\text { well-being of individuals }\end{array}$ & & & * & * \\
\hline 22 & $\begin{array}{l}\text { Identify and prevent the health risks that derive from the practice of inappropriate } \\
\text { physical activities }\end{array}$ & * & * & & \\
\hline
\end{tabular}

The different scales of teaching competencies [34] were semantically adapted to the characteristics of each of the three groups of students, graduates, and tutors. The questionnaires were constructed in three stages: (1) in an initial phase, an extensive set of questions was compiled from the literature review on the subject [35], which resulted in a first version comprising 89 questions; (2) in the second phase, the relevance (the items most related to the object of study) and clarity (easily understandable, using simple statements) of this first draft were evaluated by 9 experts in movement and physical education - members of the National Network of Formative and Shared Assessment in Spain, with a proven track record in initial teacher training and physical education-and based on data they provided, the final questions were selected; and (3) in a third phase, tests were conducted with subjects of similar characteristics to the participants in the study to ensure their comprehension. Once the questions that were unreliable and unclear according to the experts were clarified, the final scales were created, with a total of 46 items divided into three major areas [36]: (1) generic or personal competences; (2) generic 
teaching competences; and (3) specific Physical Education teaching competencies. The reliability measured by Cronbach's alpha showed very high values, specifically, in the scale of physical education teaching competencies, which was the primary focus in this work. The values were: graduates 0.931; students, 0.921 and tutors 0.954 . All were therefore above 0.7 , commonly established as the reference value for reliability.

The twenty-two competences were classified as follows [10]: specific, distinguishing between 'knowing' (A) and 'knowing how to do' (B); and generic, differentiating between 'knowing how to act' (C) and 'knowing how to be' (D). Of the twenty-two competences, eighteen had a specific character, one was generic, and three were mixed (specific and generic) (Table 2).

\subsection{Variables}

The dependent variables were the perceptions of graduates, students, and tutors about the degree of acquisition of twenty-two physical education teaching competencies. The independent variables were the type of population (graduates, students, and tutors) and the typology of the competences, organized into four groups (knowing, knowing how to do, knowing how to act, and knowing how to be) (Table 2).

\subsection{Process}

The definition of the sample and the application of the questionnaire were carried out in April 2015. We contacted some Spanish professors, and they accepted the invitation to collaborate by recruiting a large number of participants for the study. Students and their tutors from 21 Spanish universities answered paper-based questionnaires distributed in three zones: the northern zone (Universities of Valladolid, León, Burgos, Cantabria, Salamanca, País Vasco, and La Coruña), the eastern zone (Universities of Zaragoza, Lleida, Barcelona, Ramón Llull, Vic, Valencia, and the Autonomous University of Barcelona), and the central and southern zones and that of the Canary Islands (Universities of La Laguna, Alcalá, Murcia, Castilla-la Mancha, Granada, Seville, and Córdoba); the graduates were asked through an electronic questionnaire (Google), due to the difficulty in accessing this group. The approximate duration for completion was forty minutes. Previously, an informed consent form was written for all of them and anonymity was guaranteed at all times by coding the completed questionnaires.

\subsection{Data Analysis}

Two types of analysis were carried out: (1) descriptive from the means and SD of the three groups and the relative means (the order of the means within each group); (2) differences between groups using ANOVA, as there were more than two groups, and analysis of the differences between pairs of groups using the Bonferroni test. A level of significance of $p \leq 0.05$ was established. The program SPSS_v19 was used.

\section{Results}

In a global approach to the results, it was observed that the graduates presented the highest global average $(M=2.8)$, followed by students $(M=2.5)$, and finally, tutors $(M=1.4)$. The graphs of the means of the 22 items and across the three populations showed a degree of agreement, with close values between students and graduates (always higher for the latter) and both distanced from the values of the tutors (Figure 1). 


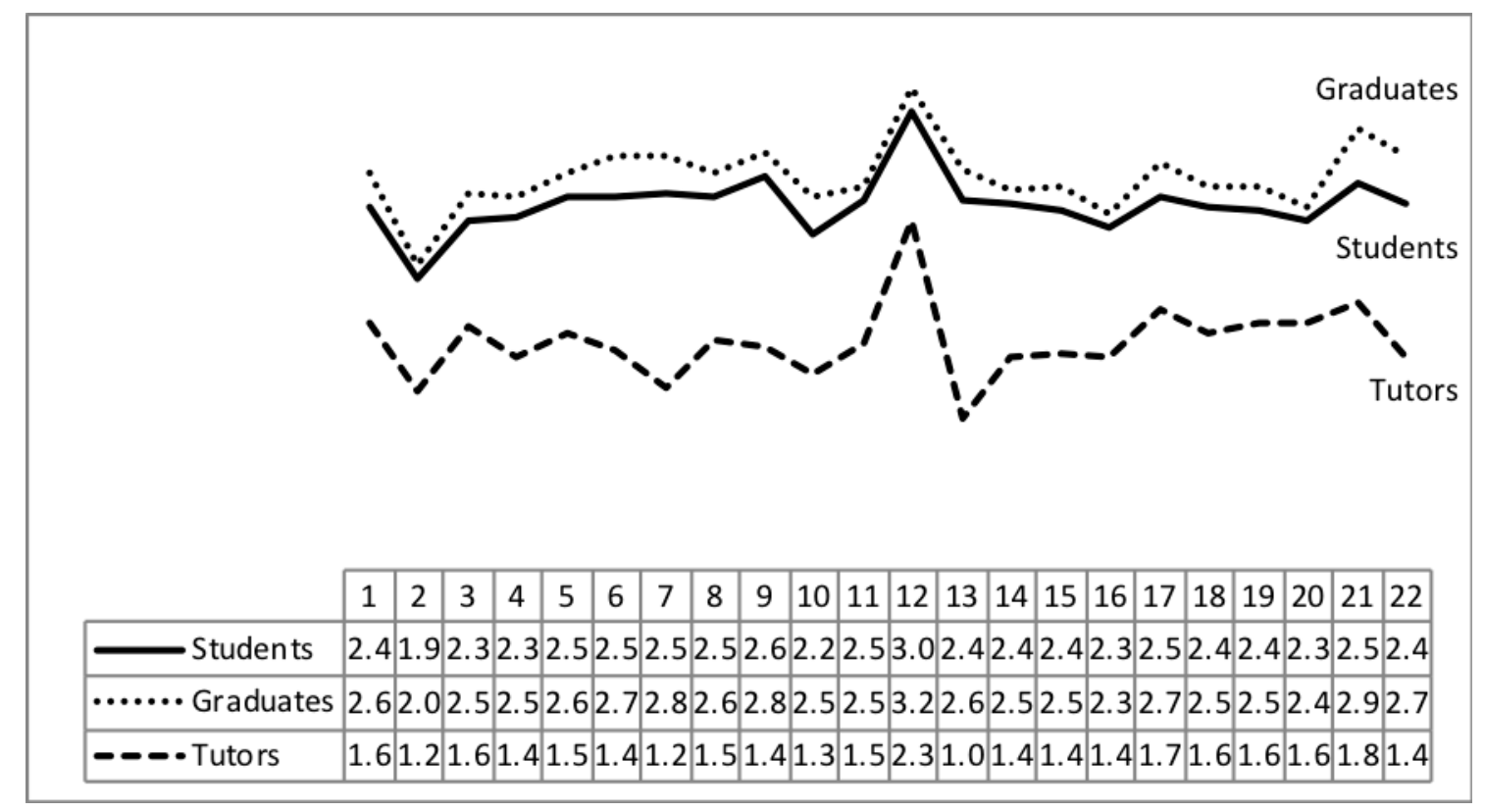

Figure 1. Graph of the means of the three groups and global average.

The range of averages for students and graduates was 1.1 points, with those of students between $\mathrm{M}=2.0$ and $\mathrm{M}=3.1$ and those of graduates between $\mathrm{M}=2.1$ and $\mathrm{M}=3.2$. For the tutors, the range was somewhat higher, 1.3 points, with the lower average being $\mathrm{M}=1.0$ and the higher $\mathrm{M}=2.4$, although the SD was higher in this group.

It was observed that the highest average in the three groups corresponded to competence 12 (motor games) and the second, but in third place for students, corresponded to competence 21 (critical ability). At the opposite extreme, competence 2 (programs for people with special needs) received the lowest value from students and graduates and the second lowest in the case of tutors.

Differences between these two groups versus tutors were also studied. The major discrepancy appeared in competence 13 (natural environment) between teachers and the other two groups; with students, the difference was 1.463 and it was 1.665 with the graduates. The smallest differences between tutors and students were in competence 3 (PE teaching-learning programs with attention to individual and context; 0.702 ) and among tutors and graduates in competence 20 (motor skills teaching-learning programs with attention to individual and context; 0.799).

Applying the ANOVA, there were significant differences $(p \leq 0.05)$ in all the competences, so the Bonferroni post hoc test was applied. Of the sixty-six possible crosses (22 items and 3 samples), significant differences were found in sixty-one of them (94.5\%). In the five items in which there was some coincidence, it was always between students and graduates: competence 2 (programs for people with special needs); 11 (acquisition of habits); 14 (EF evaluation); 16 (attention to diversity); and 20 (teaching-learning programs of motor competence with attention to the individual and context) (Table 3).

In the study of the typology of competences, the greatest differences between students and graduates as opposed to tutors were found in the specific competences related to knowledge $(7,22,9$, 6), while the smallest differences occurred in the competences relating to know-how $(20,2,3,12,19)$. This section may be divided by subheadings. It should provide a concise and precise description of the experimental results and their interpretation, as well as the experimental conclusions that can be drawn. 
Table 3. Differences between pairs of groups.

\begin{tabular}{|c|c|c|c|c|c|c|c|c|c|c|}
\hline \multirow[t]{2}{*}{$\mathbf{V}$} & \multicolumn{3}{|c|}{ ANOVA } & \multicolumn{5}{|c|}{ Comparison between Groups_Bonferroni } & \multicolumn{2}{|c|}{ 95\% Confidence Interval } \\
\hline & Quadratic Means & F & Sig. & & & Difference in Means & Standard Deviation & Sig. & Lower Limit & Upper Limit \\
\hline \multirow{4}{*}{1} & \multirow{4}{*}{105.626} & \multirow{4}{*}{121.734} & \multirow{4}{*}{0.000} & Student & Graduate & $-0.236^{*}$ & 0.05 & 0.000 & -0.35 & -0.12 \\
\hline & & & & & Tutor & 0.784 * & 0.059 & 0.000 & 0.64 & 0.93 \\
\hline & & & & Graduate & Tutor & $1.019 *$ & 0.067 & 0.000 & 0.86 & 1.18 \\
\hline & & & & Student & Graduate & -0.09 & 0.054 & 0.280 & -0.22 & 0.04 \\
\hline \multirow[t]{3}{*}{2} & \multirow[t]{3}{*}{85.064} & \multirow[t]{3}{*}{83.761} & \multirow[t]{3}{*}{0.000} & & Tutor & $0.769 *$ & 0.064 & 0.000 & 0.62 & 0.92 \\
\hline & & & & Graduate & Tutor & $0.859 *$ & 0.073 & 0.000 & 0.68 & 1.03 \\
\hline & & & & Student & Graduate & -0.182 * & 0.051 & 0.001 & -0.3 & -0.06 \\
\hline \multirow[t]{3}{*}{3} & \multirow[t]{3}{*}{81.077} & \multirow[t]{3}{*}{90.295} & \multirow[t]{3}{*}{0.000} & & Tutor & $0.702 *$ & 0.06 & 0.000 & 0.56 & 0.85 \\
\hline & & & & Graduate & Tutor & $0.884 *$ & 0.069 & 0.000 & 0.72 & 1.05 \\
\hline & & & & Student & Graduate & -0.134 * & 0.051 & 0.026 & -0.26 & -0.01 \\
\hline \multirow[t]{3}{*}{4} & \multirow[t]{3}{*}{126.976} & \multirow[t]{3}{*}{140.761} & \multirow[t]{3}{*}{0.000} & & Tutor & $0.928 *$ & 0.06 & 0.000 & 0.78 & 1.07 \\
\hline & & & & Graduate & Tutor & $1.061 *$ & 0.069 & 0.000 & 0.9 & 1.23 \\
\hline & & & & Student & Graduate & $-0.159 *$ & 0.051 & 0.006 & -0.28 & -0.04 \\
\hline \multirow[t]{3}{*}{5} & \multirow[t]{3}{*}{134.651} & \multirow[t]{3}{*}{146.022} & \multirow[t]{3}{*}{0.000} & & Tutor & 0.939 * & 0.06 & 0.000 & 0.79 & 1.08 \\
\hline & & & & Graduate & Tutor & $1.098 *$ & 0.069 & 0.000 & 0.93 & 1.26 \\
\hline & & & & Student & Graduate & $-0.276^{*}$ & 0.05 & 0.000 & -0.39 & -0.16 \\
\hline \multirow[t]{3}{*}{6} & 178.128 & 206.673 & 0.000 & & Tutor & $1.033 *$ & 0.059 & 0.000 & 0.89 & 1.17 \\
\hline & & & & Graduate & Tutor & $1.309 *$ & 0.067 & 0.000 & 1.15 & 1.47 \\
\hline & & & & Student & Graduate & $-0.267^{*}$ & 0.053 & 0.000 & -0.39 & -0.14 \\
\hline 7 & 269.463 & 276.489 & 0.000 & & Tutor & $1.309 *$ & 0.062 & 0.000 & 1.16 & 1.46 \\
\hline & & & & Graduate & Tutor & $1.577 *$ & 0.071 & 0.000 & 1.41 & 1.75 \\
\hline & & & & Student & Graduate & -0.143 * & 0.054 & 0.023 & -0.27 & -0.01 \\
\hline 8 & 143.014 & 142.084 & 0.000 & & Tutor & $0.979 *$ & 0.063 & 0.000 & 0.83 & 1.13 \\
\hline & & & & Graduate & Tutor & $1.122 *$ & 0.072 & 0.000 & 0.95 & 1.3 \\
\hline & & & & Student & Graduate & -0.170 * & 0.053 & 0.004 & -0.3 & -0.04 \\
\hline 9 & 196.254 & 201.49 & 0.000 & & Tutor & 1.151 * & 0.062 & 0.000 & 1 & 1.3 \\
\hline & & & & Graduate & Tutor & $1.322 *$ & 0.071 & 0.000 & 1.15 & 1.49 \\
\hline & & & & Student & Graduate & -0.239 * & 0.055 & 0.000 & -0.37 & -0.11 \\
\hline 10 & 143.777 & 133.896 & 0.000 & & Tutor & 0.935 * & 0.065 & 0.000 & 0.78 & 1.09 \\
\hline & & & & Graduate & Tutor & 1.174 * & 0.075 & 0.000 & 0.99 & 1.35 \\
\hline & & & & Student & Graduate & -0.08 & 0.052 & 0.377 & -0.2 & 0.05 \\
\hline 11 & 129.809 & 136.101 & 0.000 & & Tutor & $0.962 *$ & 0.062 & 0.000 & 0.81 & 1.11 \\
\hline & & & & Graduate & Tutor & $1.042 *$ & 0.071 & 0.000 & 0.87 & 1.21 \\
\hline & & & & Student & Graduate & -0.165 * & 0.049 & 0.002 & -0.28 & -0.05 \\
\hline 12 & 87.036 & 102.289 & 0.000 & & Tutor & $0.729 *$ & 0.057 & 0.000 & 0.59 & 0.87 \\
\hline & & & & Graduate & Tutor & $0.895 *$ & 0.066 & 0.000 & 0.74 & 1.05 \\
\hline
\end{tabular}


Table 3. Cont

\begin{tabular}{|c|c|c|c|c|c|c|c|c|c|c|}
\hline \multirow[t]{2}{*}{$\mathbf{V}$} & \multicolumn{3}{|c|}{ ANOVA } & \multicolumn{5}{|c|}{ Comparison between Groups_Bonferroni } & \multicolumn{2}{|c|}{ 95\% Confidence Interval } \\
\hline & Quadratic Means & F & Sig. & & & Difference in Means & Standard Deviation & Sig. & Lower Limit & Upper Limit \\
\hline \multirow{4}{*}{13} & \multirow{4}{*}{314.489} & \multirow{4}{*}{316.532} & \multirow{3}{*}{0.000} & Student & Graduate & $-0.202 *$ & 0.053 & 0.000 & -0.33 & -0.07 \\
\hline & & & & & Tutor & $1.463 *$ & 0.063 & 0.000 & 1.31 & 1.61 \\
\hline & & & & Graduate & Tutor & $1.665 *$ & 0.072 & 0.000 & 1.49 & 1.84 \\
\hline & & & \multirow{3}{*}{0.000} & Student & Graduate & -0.088 & 0.057 & 0.383 & -0.23 & 0.05 \\
\hline \multirow{3}{*}{14} & \multirow{2}{*}{146.499} & \multirow{2}{*}{127.114} & & & Tutor & $1.025 *$ & 0.068 & 0.000 & 0.86 & 1.19 \\
\hline & & & & Graduate & Tutor & $1.113 *$ & 0.078 & 0.000 & 0.93 & 1.3 \\
\hline & \multirow{4}{*}{140.499} & \multirow{4}{*}{141.493} & \multirow{4}{*}{0.000} & Student & Graduate & -0.150 * & 0.053 & 0.015 & -0.28 & -0.02 \\
\hline \multirow[t]{3}{*}{15} & & & & & Tutor & $0.973 *$ & 0.063 & 0.000 & 0.82 & 1.12 \\
\hline & & & & Graduate & Tutor & $1.123 *$ & 0.072 & 0.000 & 0.95 & 1.3 \\
\hline & & & & Student & Graduate & -0.087 & 0.055 & 0.345 & -0.22 & 0.05 \\
\hline \multirow[t]{3}{*}{16} & \multirow{3}{*}{109.905} & \multirow[t]{3}{*}{102.538} & \multirow[t]{3}{*}{0.000} & & Tutor & $0.878 *$ & 0.065 & 0.000 & 0.72 & 1.03 \\
\hline & & & & Graduate & Tutor & $0.966 *$ & 0.075 & 0.000 & 0.79 & 1.15 \\
\hline & & & & Student & Graduate & $-0.229 *$ & 0.054 & 0.000 & -0.36 & -0.1 \\
\hline \multirow[t]{3}{*}{17} & \multirow[t]{3}{*}{98.623} & \multirow[t]{3}{*}{95.998} & \multirow[t]{3}{*}{0.000} & & Tutor & $0.755^{*}$ & 0.064 & 0.000 & 0.6 & 0.91 \\
\hline & & & & Graduate & Tutor & $0.983 *$ & 0.073 & 0.000 & 0.81 & 1.16 \\
\hline & & & & Student & Graduate & $-0.142 *$ & 0.05 & 0.013 & -0.26 & -0.02 \\
\hline \multirow[t]{3}{*}{18} & \multirow[t]{3}{*}{106.916} & \multirow[t]{3}{*}{122.877} & \multirow[t]{3}{*}{0.000} & & Tutor & $0.838 *$ & 0.059 & 0.000 & 0.7 & 0.98 \\
\hline & & & & Graduate & Tutor & $0.980 *$ & 0.067 & 0.000 & 0.82 & 1.14 \\
\hline & & & & Student & Graduate & -0.169 * & 0.05 & 0.002 & -0.29 & -0.05 \\
\hline 19 & 92.326 & 107.409 & 0.000 & & Tutor & $0.762 *$ & 0.059 & 0.000 & 0.62 & 0.9 \\
\hline & & & & Graduate & Tutor & 0.931 * & 0.067 & 0.000 & 0.77 & 1.09 \\
\hline & & & & Student & Graduate & -0.091 & 0.051 & 0.214 & -0.21 & 0.03 \\
\hline 20 & 73.19 & 82.101 & 0.000 & & Tutor & $0.707^{*}$ & 0.06 & 0.000 & 0.56 & 0.85 \\
\hline & & & & Graduate & Tutor & $0.799 *$ & 0.068 & 0.000 & 0.64 & 0.96 \\
\hline & & & & Student & Graduate & $-0.367 *$ & 0.05 & 0.000 & -0.49 & -0.25 \\
\hline 21 & 132.675 & 154.157 & 0.000 & & Tutor & $0.792 *$ & 0.058 & 0.000 & 0.65 & 0.93 \\
\hline & & & & Graduate & Tutor & $1.159 *$ & 0.067 & 0.000 & 1 & 1.32 \\
\hline & & & & Student & Graduate & $-0.316^{*}$ & 0.053 & 0.000 & -0.44 & -0.19 \\
\hline 22 & 186.372 & 188.2 & 0.000 & & Tutor & $1.033 *$ & 0.063 & 0.000 & 0.88 & 1.18 \\
\hline & & & & Graduate & Tutor & $1.349 *$ & 0.072 & 0.000 & 1.18 & 1.52 \\
\hline
\end{tabular}




\section{Discussion}

Summary. The results of our study showed that students and graduates considered that they acquired, to a large extent, the teaching competences in PE, while their tutors perceived a lower level of acquisition of the competences by the students and graduates. The opinions of students and graduates coincided in somewhat more than a quarter of the competences, while the tutors maintained significant differences with the other two groups with regard to all of them. However, there was an almost perfect coincidence between the three groups as to which competences were the most acquired (critical ability and motor play) and which were the least (programs for people with special needs). Regarding skills typologies, the greatest differences were seen between students and graduates, as opposed to tutors, in the knowledge category and the smallest differences were seen in the competency of know-how.

Global data. In the present study, based on the perceptions of these educational agents, we found agreements with the findings of [37], who attributed to the evaluation of the perceptions of students and tutors an even more relevant role than systematic observation or the study of cases. This is because it has the advantage of being based on the evaluation of the effective experience of the students within a specific environment and incorporates the judgments of all the members of the class group. On the other hand, evaluations made based on the collection of student information are useful for improving the quality of teaching because they are relatively valid and are not influenced by potential biases [38]. In addition, some limitations of research on student perceptions are derived from the lack of contrast with the tutor's assessment [39], but this did not happen in our study as it includes tutors within the sample.

The results of our study produced satisfactory data in that both students and graduates perceived they had acquired the necessary PE teaching competences to a large extent. The graduates, who provided the highest averages, considered that the level of skills they acquired was $\mathrm{M}=2.8$, close to a lot. The students were placed in an intermediate-high category (the global average was $\mathrm{M}=2.5$, between moderate and a lot). So, if a person can be considered competent when he or she is capable of solving problems specific to their field of activity [40] and of applying appropriate competencies to a variety of situations [41], we could say that both students and graduates perceived themselves to be between average and very prepared to deal with the demands of the profession; that is, to resolve issues in professional teaching situations. The high values given by the graduates have great relevance when considering this group as, having recently completed one of the degree courses being studied here, they have a practical appreciation of the usefulness of their studies that provide experiences relative to the professional context. Therefore, they can analyze, with a good degree of perspective, the strengths and weaknesses of the courses they have experienced. However, the tutor group perceived a low level of acquisition of the competences by their students or alumni. The lowest averages always occurred in this group $(M=1.4)$, who considered the required competences had only been acquired to a little or moderate degree.

Similarities. Of the five competences for which the differences between students and graduates were not significant, three of them have a similar nature because they all relate to taking into account the individual characteristics of the people to whom teaching-learning processes are applied: competence 2 (special educational needs, $\mathrm{M}=2$ ); competence 16 (diversity of the students, $\mathrm{M}=2.3$ ); and competence 20 (individual and contextual characteristics, $M=2.4$ ). Given that the three are located in or close to the moderate category we cannot say that these data indicate a satisfactory position.

Reinforcing the data analyzed above, in relation to the competences acquired to a lesser degree, there was an almost total coincidence between the three groups with regard to competence 2 (programs for people with special needs): graduates and students awarded the lowest average (moderately acquired) and tutors put it in second place (little acquired). This leads us to believe that this is an area that has not been adequately addressed within initial teacher training, as suggested above. Particularly if we take into account that knowing how to manage heterogeneity represents a key competence in teacher education [42]. 
Differences. The ANOVA data showed some significant differences in perceptions about the 22 competencies. In analyzing which pairs of groups produced these differences, it was observed that they occurred in all possible crosses except in five of the student-graduate pairs.

Therefore, there was an important discrepancy between the opinions of tutors vs. students and graduates, unlike the findings in [38], in which the degree of agreement between tutors and students in each dimension of their study was significant.

Although in our study there were significant differences between the three groups, except for the five mentioned crossings where students and graduates coincided, the analysis of the relative values (the order of each mean with respect to their group) showed that there were coincidences about what competencies were the least and most valued by all groups. This was also observed in the profiles, partially similar, between the three graphs (Figure 1). We consider that the coinciding opinion of three different groups gives the data great stability. The three groups gave their highest value to competence 12 (motor games), followed closely by competence 21 (critical ability).

Games have long been a key element of content in the compulsory PE curricula [43], which undoubtedly seems to be reflected in initial training programs. Also, the fact that games are included in university curricula, as content and as a methodological resource (recreational methodologies are frequently referenced in the programs), has been able to influence the significant consideration that students, graduates, and tutors all give to this competence. Nevertheless, regarding PETE, new learning trends are emerging in the 21th century. One of them is the transition to more health-based curriculum [44,45], and another one is the beginning of a new neuroscience contribution to curriculum theory [46].

Regarding the reference to the natural environment, tutors produced a lower average score and the biggest difference between their perception and that of students and graduates, probably as a result of the different appreciation of the material conditions in which this type of activity is developed.

On the other hand, that fact that the competence related to critical ability presented one of the highest average scores is very positive, given that the development of a critical and reflective attitude is in line with the university model of education currently being implemented, which is focused on the student and on the competences that he/she must acquire. These, as we mentioned in the introduction [10], are not only knowledge and know-how, but also personal competences such as knowing how to act or knowing how to be. The importance of the reflective professional as an agent of change has been pointed out [40]. That is the reason why tutors must learn to adapt following reflection [47]. As a result, reflective practice and critical involvement would be, rather than competences, "fundamental behaviors" to be acquired through teacher education [42] (p. 506). Equally, the job of teaching within current parameters stresses the need for reflection in practice [48]. Clearly, the professional approach to university education, as expected by society, should include systematic reflection by all involved on their own actions [49].

Finally, according to society expectations, labor market, and scientific evidence, it would be interesting for university faculty to offer quality training to tutors and partners to have more alignment with expectations and methodologies. Perhaps some current academic competences are misaligned with these issues.

\section{Conclusions}

In conclusion, the results allow us to be partially optimistic, at least from the opinion of students and graduates, in particular of the latter, regarding the degree of acquisition of specific teaching competencies in a context where the professional profiles of university degrees are characterized by addressing multiple and complex competencies to respond to multiple and complex jobs [12]. Resulting from this is a need to delve deeper into the reasons for the low values expressed by the tutors and the differences that may arise between degrees that are not studied here due to reasons of the dimension of the study. 
It has become evident that there is a need to continue reflecting on what formative aspects tutors attribute importance to in comparison to students. It seems that everything that relates to conceptual knowledge has a great significance for tutors, while students are more oriented to knowing how to do things, to practical knowledge, and ways to apply that knowledge; this is something that has been reiterated in this research and that future educational models should continue to develop.

Critical and reflexive capacity has been shown to be important in this study; without doubt the teaching professionals demanded by society must take all this into account. Therefore, it will be necessary to study and influence, in even greater depth, research into this area and its operational implementation within PETE, since it is based on the logic of training plans that are focused on competencies where that approach becomes essential.

The aspects that refer to the individualization, diversity, and special educational needs of the practical proposals that future tutors should implement in their professional contexts, are highlighted as an area in which future training needs to be influenced.

All of these proposals for improvements should probably be implemented by viewing educational methods from a modular perspective and getting tutors to work in teams in order to ensure all competences are acquired effectively [12].

Author Contributions: S.A. conceptualization, validation, writing—original draft, writing — review and editing, visualization, funding acquisition. M.T.C. validation, resources, software, supervision, and funding acquisition. M.R.R. conceptualization, methodology, data curation, project administration, funding acquisition. All authors have read and agreed to the published version of the manuscript.

Funding: This study has been funded by the Spanish Government through the State Program of Research, Development, and Innovation Oriented to the Challenges of Society, within the framework of the State Plan for Scientific and Technical Research and Innovation, 2013-2016 (Spain) (EDU 2013-42024-R): «Teaching competences in the initial training of Physical Education Teachers».

Acknowledgments: First, we would like to thank the members of the National Network for Formative and Shared Assessment and the network itself for the distribution and application of the questionnaires to tutors and students in all the Spanish universities. We also thank the 24 Spanish universities involved in the study for their collaboration. Finally, we thank all the students, graduates, and tutors who participated in the sample of this study, and for their indispensable contribution to our research.

Conflicts of Interest: The authors declare no conflict of interest. The funders had no role in the design of the study; in the collection, analyses, or interpretation of data; in the writing of the manuscript; or in the decision to publish the results.

\section{References}

1. Allen, J.; Van den Vernen, R. Educational Mismatches versus Skill Mismatches: Effects on Wages, Job Satisfaction, and On-the-Job Search. Oxf. Econ. Pap. 2001, 53, 434-552. [CrossRef]

2. Amor, M.I.; Serrano, R. The generic competences in the initial teacher training a comparative study among students, teachers and graduates of University Education Degree. Educ. Xx1 2019, 22, 239-261. [CrossRef]

3. Cañadas, L.; Santos-Pastor, M.; Castejón, J. Desarrollo de competencias docentes en la formación inicial del profesorado de Educación Física. Estud. Pedag. 2018, 44, 111-126. [CrossRef]

4. Gallardo-Fuentes, F.; López-Pastor, V.; Carter-Tuhillier, B. Efectos de la Aplicación de un Sistema de Evaluación Formativa en la Autopercepción de Competencias Adquiridas en Formación Inicial del Profesorado. Estud. Pedag. 2018, 44, 55-77. [CrossRef]

5. Hortigüela, D.; Palacios, A.; López-Pastor, V. The impact of formative and shared or co-assessment on the acquisition of transversal competences in higher education. Assess. Eval. High. Educ. 2018, 44, 933-945. [CrossRef]

6. Ramírez-García, A.; González-Fernández, N.; Salacines-Talledo, I. Las Competencias Docentes Genéricas en los Grados de Educación. Visión del Profesorado Universitario. Estud. Pedag. 2018, 44, $259-277$.

7. Mah, D.K.; Ifenthaler, D. Student's perceptions toward academic competencies. The case of German first year students. Issues Educ. Resea. 2018, 28, 120-138.

8. Prokou, E. The emphasis on employability and the changing role of the university in Europe. High. Educ. Eur. 2008, 33, 387-394. [CrossRef] 
9. Martínez, P.; González, C.; Rebollo, M. Competencias para la empleabilidad: Un modelo de ecuaciones estructurales para la Facultad de Educación. Rev. Investig. Educ. 2018, 37, 57-73. [CrossRef]

10. Echeverría, B. Gestión de la competencia de acción profesional. Rev. Investig. Educ. 2002, 20, 7-43.

11. Schippmann, J.S.; Ash, R.A.; Battista, M.; Carr, L.; Eyde, L.D.; Hesketh, B.; Kehoe, J.; Pearlman, K.; Prien, E.p.; Sanchez, J.I. The practice of competency modeling. Pers. Psychol. 2000, 53, 703-740. [CrossRef]

12. Yániz, C. Las competencias en el currículo universitario: Implicaciones para diseñar el aprendizaje y para la formación del profesorado. Guías PoliPapers 2008, 1, 1-14.

13. Perrenaud, P. Dix Nouvelles Compétences Pour Enseigner, 1st ed.; EPS: Paris, France, 2009; pp. 7-16.

14. Pérez-Gómez, A. Aprender a educar. Nuevos desafíos para la formación de docentes. Rev. Interuniv. Form. Profr. 2010, 68, 37-60.

15. Giovanelli, M. Relationship between reflective disposition toward teaching and effective teaching. J. Educ. Res. 2003, 96, 293-309. [CrossRef]

16. Devine, D.; Fahie, D.; McGillicuddy, D. What is 'good' teaching? Teacher beliefs and practices about their teaching. Ir. Educ. Stud. 2013, 32, 83-108. [CrossRef]

17. González, A.; Conde, A.; Díaz, P.; García, M.; Ricoy, C. Instructor's teaching styles: Relations whith competences, self-efficacy and commitment in pre-service teachers. High. Educ. 2018, 75, 625-642. [CrossRef]

18. Meng, L.; Muñoz, M.A.; Wu, D. Teachers' perceptions of effective teaching: A theory-based exploratory study of teachers from China. Educ. Psychol. 2016, 36, 461-480. [CrossRef]

19. Reoyo, N.; Carbonero, M.A.; Marín, L. Características de eficacia docente desde las perspectivas del profesorado y futuro profesorado de secundaria. Rev. Educ. 2017, 376, 62-86. [CrossRef]

20. Medina, A.; Domínguez, M.C.; Sánchez, C. Evaluación de las competencias de los estudiantes: Modelos y técnicas para la valoración. Rev. Investig. Educ. 2013, 31, 239-255. [CrossRef]

21. Ross, S.; Metcalf, A.; Bulger, S.M.; Housner, L.D. Modified Delphi Investigation of Motor Development and Learning in Physical Education Teacher Education. Res. Q. Exerc. Sport 2014, 85, 316-329. [CrossRef]

22. Hodge, S.R.; Davis, R.; Woodard, R.; Sherrill, C. Comparison of practicum types in changing preservice teachers' attitudes and perceived competence. Adapt. Phys. Act. Q. 2002, 19, 155-171. [CrossRef] [PubMed]

23. Chernikova, O.; Heitzmann, N.; Fink, M.C.; Timothy, V.; Seidel, T.; Fischer, F. Facilitating diagnostic competences in Higher Education_a Meta-Analysis in Medical and Teacher Education. Educ. Psychol. Rev. 2020, 32, 157-196. [CrossRef]

24. Trevitt, C.; Breman, E.; Stocks, C. Assessment and learning: Is it time to rethink student activities and academic roles. Rev. Investig. Educ. 2012, 30, 253-269.

25. Villa, A.; Campo, L.; Arranz, S.; Villa, O.; García, A. Valoración del profesorado de magisterio sobre el aprendizaje basado en competencias implantado. Profr. Rev. Curric. Profr. 2013, 17, 35-55.

26. Shivoro, R.S.; Shalyefu, R.K.; Kadhila, N. Perspectives on graduate employability attributes for management sciences graduates. S. Afr. J. High. Educ. 2018, 32, 216-232. [CrossRef]

27. Arribas, J.M.; Manrique, J.C.; Tabernero, B. Instrumentos de evaluación utilizados en la formación inicial del profesorado y su coherencia para el desarrollo de competencias profesionales en los estudiantes: Visión del alumnado, egresados y profesorado. Rev. Comp. Educ. 2016, 27, 237-255.

28. Norris, J.M.; van der Mars, H.; Kulina, P.; Amrein-Beardsley, A.; Kwon, J.; Hodges, M. Physical Education Teacher Perceptions of Teacher Evaluation. Physiol. Educ. USA 2017, 74, 41-62. [CrossRef]

29. Gutiérrez-García, C.; Pérez-Pueyo, A.; Pérez-Gutiérrez, M.; Palacios-Picos, A. Percepciones de profesores y alumnos sobre la enseñanza, evaluación y desarrollo de competencias en estudios universitarios de formación del profesorado. Cult. Educ. 2012, 23, 499-514. [CrossRef]

30. Kovac, M.; Sloan, S.; Starc, G. Competencies in physical education teaching: Slovenian teachers' views and future perspectives. Eur. Phys. Educ. Rev. 2008, 14, 299-323. [CrossRef]

31. Creswell, J.W. Educational Research. Planning, Conducting and Evaluating Quantitative and Qualitative Research, 4th ed.; Pearson: Boston, CA, USA, 2012; pp. 140-157.

32. Agencia Nacional de Evaluación de la Calidad y la Acreditación. Libro Blanco. Título de Grado en Magisterio, 1st ed.; Agencia Nacional de la Evaluación de la Calidad y la Acreditación: Madrid, España, 2005; pp. 90-110.

33. Agencia Nacional de Evaluación de la Calidad y la Acreditación. Libro Blanco. Título de Grado en Ciencias de la Actividad Física y el Deporte, 1st ed.; Agencia Nacional de la Evaluación de la Calidad y la Acreditación: Madrid, España, 2005; pp. 257-264. 
34. González, J.; Wagenaar, R. Tuning Educational Structures in Europe, 1st ed.; Universidad de Deusto: Bilbao, España, 2003; pp. 26-31.

35. Álvarez, M.; Asensio, I.; García, J.M. Deporte y competencias genéricas en la universidad: Diseño y validación del (competest). Rev. Comp. Educ. 2013, 24, 141-163.

36. Díaz del Cueto, M. Cómo se Forma el Profesorado de Educación Física. Las Competencias en los Planes de Formación; Editorial Grao: Barcelona, Spain, 2013; Volume 43, pp. 28-38.

37. Moreira, L.M.; Santos, M.A. Evaluando la enseñanza en la Educación Superior: Percepciones de docentes y discentes. Rev. Elect. Investig. Educ. 2016, 18, 19-36.

38. Marsh, H.W. Students' evaluation of university teaching: Resea. Find. Int. J. Educ. Res. 1987, 11, $253-388$. [CrossRef]

39. Hortigüela, D.; Abella, V.; Delgado, V.; Ausín, V. Influencia del sistema de evaluación empleado en la percepción del alumno sobre su aprendizaje y las competencias docentes. Inf. Educ. Apr. 2016, 2, $20-42$.

40. Gairín, J. La formación de profesores basada en competencias. Bordon 2011, 63, 93-108.

41. Zarifian, P. Le modèle de la Compétence, 1st ed.; Liaisons: París, France, 2004; pp. 78-105.

42. Perrenaud, P. La formación de los docentes en el siglo XXI. Rev. Tecnol. Educ. 2001, 14, 503-523.

43. Devis, J. El juego en el currículum de la Educación Física: Aproximación crítica (o el reino de lo posible en la postmodernidad). Rev. Educ. Fís. Deporte 2008, 27, 79-89.

44. Wilkinson, C.; Prusak, K.; Zanandrea, M. Developing HALM Teaching Competencies in PETE Teacher Candidates. J. Phys. Educ. Recreat. Dance 2018, 89, 19-29. [CrossRef]

45. Brandl-Bredenbeck, H.P.; Sygush, R. High Way to Health- an innovative way to adress Health in Physical Education Teacher Education (PETE). Retos Nuevas Tend. Educ. Fís. Recreación 2017, 31, 221-326.

46. Nouri, A.; Mehurmohammadi, M.; Kharrazi, K. The place of Neuroscience in Curriculum Thought and Practice. World Appl. Sci. J. 2014, 31, 591-600.

47. Aparicio, J.L.; Fraile, A. Las competencias interpersonales en la formación del profesorado de educación física a través de un programa de expresión corporal. Int. J. 21st Cent. Educ. 2016, 10, 21-34.

48. Pavié, A. Formación docente: Hacia una definición del concepto de competencia profesional docente. Rev. Electrón. Interuniv. Form. Profr. 2011, 14, 67-80.

49. Barnett, R. Los limites de la Competencia: El Conocimiento, la Educación Superior y la Sociedad, 1st ed.; Gedisa: Barcelona, España, 2001; pp. 24-75. 